Indogermanische Forschungen 



\section{Indogermanische Forschungen}

Zeitschrift für Indogermanistik und historische Sprachwissenschaft

Begründet von

Karl Brugmann und Wilhelm Streitberg

Herausgegeben von

Benjamin Fortson, Götz Keydana, Melanie Malzahn und Paul Widmer

126. Band

2021

DE GRUYTER 
Alle für die Indogermanischen Forschungen bestimmten Beiträge reichen Sie bitte über das Einreichungsportal ein unter: https://mc.manuscriptcentral.com/indo

oder senden Sie per Briefpost an:

Sprachwissenschaftliches Seminar der Georg-August-Universität Göttingen, Indogermanische Forschungen, Käte-Hamburger-Weg 3, D-37073 Göttingen.

Wissenschaftlicher Beirat:

Daniel Petit (Paris), Elisabeth Rieken (Marburg), Stefan Schumacher (Wien), Guðrún Pórhallsdóttir (Reykjavík), Michael Weiss (Ithaca, NY)

ISSN 0019-7262

e-ISSN 1613-0405

\section{Bibliografische Information der Deutschen Nationalbibliothek}

Die Deutsche Nationalbibliothek verzeichnet diese Publikation in der Deutschen Nationalbibliografie; detaillierte bibliografische Daten sind im Internet über http://dnb.dnb.de abrufbar.

(C) 2021 Walter de Gruyter GmbH, Berlin/Boston

Druck und Bindung: $\mathrm{CPI}$ books $\mathrm{GmbH}$, Leck

www.degruyter.com 